\title{
Titae
}

$35(2019) 561-564$

\section{Krzysztof Mielcarek}

Katolicki Uniwersytet Lubelski Jana Pawła II

krzysztof.mielcarek@kul.pl, ORCID:0000-0001-8575-7966

\section{Brant Pitre, Jezus i żydowskie korzenie Eucharystii (Kraków: WAM 2018). Ss. 240. PLN 40,40. ISBN 978-83-277-1583-8}

Dr Brant Pitre należy do młodego pokolenia świeckich biblistów katolickich, którzy nie tylko charakteryzują się szeroką wiedzą, ale również znakomicie odnajdują się w popularyzacji ważnych tematów związanych z Pismem Świętym. Jego książki są wydawane w dużych nakładach i bardzo dobrze przyjmowane zarówno przez specjalistów, jaki i szersze grono odbiorców. Wśród nich warto wymienić Jesus and the Jewish Roots of Mary (New York: Image 2018), A Catholic Introduction to the Bible: Old Testament (wspólautor John Bergsma) (San Francisco, CA: Ignatius 2018), The Case for Jesus. The Biblical and Historical Evidence for Christ (New York: Image 2016), Jesus and the Last Supper (Grand Rapids, MI: Eerdmans 2015) oraz Jesus the Bridegroom. The Greatest Love Story Ever Told (New York: Image 2014). Dobrze się zatem stało, że jego książka Jezus $i$ żydowskie korzenie Eucharystii, wydana w oryginale angielskim przez wydawnictwo Doubleday (Jesus and the Jewish Roots of the Eucharist: Unlocking the Secrets of the Last Supper (New York: Doubleday 2011), została przetłumaczona na język polski. Warto zaznaczyć, że ma ona także swoje unikalne tło, wynikające 
z życiowej drogi autora. Brant Pitre poślubił bowiem baptystkę, co zmusiło go do żywego dialogu z protestantami na temat biblijnych podstaw sakramentalnego wymiaru tradycji Kościoła katolickiego.

Książka Pitre’a składa się z siedmiu rozdziałów, które kolejno omawiają istotne dla rozumienia Eucharystii tematy. W rozdziale pierwszym autor podejmuje próbę wyjaśnienia nauki Jezusa o spożywaniu Jego ciała w świetle Prawa Starego Testamentu. Rozdział drugi jest prezentacją kluczowych tekstów biblijnych i źródeł żydowskich charakteryzujących eschatologiczne oczekiwania starożytnych Żydów (nowy Mojżesz, nowe Przymierze, nowa Świątynia i nowa Ziemia Obiecana). Kolejny, trzeci rozdział poświęcony został obrazowi Jezusa jako Nowego Paschalnego Baranka w świetle ewangelicznych opowiadań paschalnych. Szczególnie cenna wydaje się zawarta w nim aluzja do żydowskiego widzenia baranków paschalnych jakby „ukrzyżowanych”, do czego nawiązywał również Justyn Męczennik. Rozdział czwarty jest analizą nauk Jezusa na temat Nowej Manny, czyli „chleba aniołów”. Tradycja zawarta w psałterzu (Ps 78,23-25.29) została podjęta w świetle wygłoszonej po cudzie rozmnożenia chleba tzw. mowy eucharystycznej Jezusa z czwartej Ewangelii (J 6).

Chleby pokładne (oblicza/obecności), które przechowywano w Miejscu Świętym w Świątyni Jerozolimskiej, stały się przedmiotem refleksji w rozdziale piątym, ponieważ były one łączone przez pierwszych chrześcijan z przekazem o Eucharystii. W rozdziale szóstym Pitre pozwala sobie na odrobinę spekulacji w budowaniu historycznego tła Ostatniej Wieczerzy. Odwołując się do żydowskiej liturgii paschalnej, zwraca uwagę na podobieństwo między rytem żydowskiej Paschy i przekazami o uczcie paschalnej Jezusa z uczniami (Łk 22,17.20). To podobieństwo jest widoczne zwłaszcza w kolejnych kielichach wypijanych podczas uroczystości. W tradycji żydowskiej trzeci kielich był bowiem nazywany kielichem błogosławieństwa, co przywodzi na myśl Pawłowy opis eucharystyczny (1 Kor 10,16). Zdaniem autora 
słowa Jezusa powtarzane codziennie w celebracji eucharystycznej zostały przez Niego wypowiedziane nad "trzecim” kielichem liturgii paschalnej, ale czwarty kielich uczty paschalnej został dopełniony dopiero z wysokości krzyża.

Ostatni, siódmy rozdział książki odsłania wczesnochrześcijańskie źródła eucharystycznych inspiracji autora. Ojcowie apostolscy i teologowie pierwszych wieków jako pierwsi dostrzegli powiązania Eucharystii z starotestamentowymi obrazami manny i chlebów pokładnych.

Pitre stara się by jego studium było zrozumiałe dla każdego, ale nie oznacza to rezygnacji z naukowej rzetelności w dochodzeniu do prawdy. Przeciwnie, wykorzystując dzieła katolickie (Benedykt XVI, J.P. Meier, B. Meyer), protestanckie (N.T. Wright, C. Evans, E.P. Sanders) i żydowskie (D. Flusser, G. Vermes, A.J. Levine, J. Klausner) stara się odwoływać do różnorodnych i niezależnych źródeł. W razie potrzeby sięga po opracowania nawet z początku XX wieku, ale dbając o komfort czytelnika umieszcza przypisy na końcu książki. W ten sposób jej lektura może odbywać się bez zbędnego obciążania odbiorcy aparatem naukowym.

$Z$ dużym znawstwem wykorzystuje również źródła rabiniczne (Miszna, Talmud babiloński), wykazując wiele podobieństw do treści spotykanych w Ewangeliach. Dzięki temu czytelnik może przekonać się o istniejącej ciągłości między żydowskimi oczekiwaniami okresu międzytestamentalnego a chrześcijaństwem, zwłaszcza w odniesieniu do eschatologii, czyli czasów ostatecznego spełnienia Bożych planów - czasów mesjańskich. W świetle nauki rabinów przyszły Mesjasz będzie „nowym Mojżeszem”, który ofiaruje ludowi „chleb z nieba”. W podobnej perspektywie ewangelie przedstawiają Jezusa, który jak Mojżesz pości przez czterdzieści dni i składa obietnicę udzielenia prawdziwej manny (J 6). $\mathrm{Na}$ końcu książki autor ujawnia także znajomość literatury wczesnochrześcijańskiej, która stała się dla niego źródłem inspiracji w poszukiwaniach pomostów pomiędzy Eucharystią i światem żydowskim. 
Książka amerykańskiego egzegety przekonująco ukazuje skalę głębokiego nasycenia całego Nowego Testamentu różnorodnymi odniesieniami do żydowskich oczekiwań. Te nawiązania występują nawet w najbardziej oczywistych fragmentach i modlitwach chrześcijańskich, takich jak „Ojcze nasz", chociaż wielu uczniów Chrystusa ich nie zauważa. Dla przykładu, Pitre stwierdza, że pozornie pleonastyczne wyrażenie prośby o „chleb powszedni”, którego Bóg ma udzielać ludziom codziennie, jest w rzeczywistości świadomym odwołaniem się do wydarzeń doświadczanych przez lud Izraela na pustyni. Redaktor Księgi Wyjścia podkreślał bowiem, że Bóg dzień po dniu karmił swój lud na pustkowiu (Wj 16). Również żydowskie tradycje dostępne współcześnie w literaturze rabinicznej mogą być w wielu wypadkach świadkiem przekazów istniejących już w czasach Jezusa i jako takie stanowić cenną pomoc w wyjaśnianiu wielu fragmentów Nowego Testamentu.

Aktualność i duchowe bogactwo treści przedstawionych przez Pitre’a sprawia, że książka Jezusiżydowskiekorzenie Eucharystii powinna być lekturą obowiązkową dla wszystkich, którzy chcą lepiej zrozumieć żydowski i wczesnochrześcijański kontekst Najświętszego Sakramentu. Czytelnikom z kręgu tradycji protestanckiej pomoże lepiej zrozumieć głębię zakorzenienia liturgii eucharystycznej w Biblii. Tym zaś, którzy w ramach tradycji katolickiej dystansują się od żydowskich korzeni chrześcijaństwa, skupiając się jedynie na sakramentalnym wymiarze Kościoła, da okazję do refleksji na temat więzów łączących Synagogę z Kościołem. Paradoksalnie, uświadomienie sobie tych związków pozwoli im lepiej przeżywać bogactwo tajemnicy Sakramentu Miłości. Lektura tej książki może okazać się także ciekawym wyzwaniem dla wyznawców judaizmu, którzy ze zdziwieniem odkryją, że chrześcijaństwo jest w wielu wymiarach raczej kontynuacją niż zaprzeczeniem ich religijnych przekonań. 